\title{
Effects of dietary concentrate supplementation on enteric methane emissions and performance of late lactation dairy cows
}

\author{
Camila Muñoz ${ }^{1 *}$, Denisse Herrera ${ }^{2}$, Sara Hube ${ }^{1}$, Jorge Morales ${ }^{1}$, and Emilio M. Ungerfeld ${ }^{3}$ \\ ${ }^{1}$ Instituto de Investigaciones Agropecuarias, INIA Remehue, Casilla 24-0, Osorno, Chile. \\ *Corresponding author (camila.muñoz@inia.cl). \\ ${ }^{2}$ Universidad Mayor, Facultad de Ciencias Silvoagropecuarias, Camino La Pirámide N5750, Huechuraba, Santiago, Chile. \\ ${ }^{3}$ Instituto de Investigaciones Agropecuarias, INIA Carillanca, km 10, Camino Cajón, Vilcún, Temuco, Chile.
}

Received: 9 April 2018; Accepted: 20 July 2018; doi:10.4067/S0718-58392018000300429

\begin{abstract}
Dietary supplementation with concentrates is regarded as an effective strategy to decrease the intensity of methane $\left(\mathrm{CH}_{4}\right)$ emissions, although it has rarely been evaluated in late lactation dairy cows. The aim of the present study was to investigate the effects of two levels of dietary concentrate supplementation on $\mathrm{CH}_{4}$ emissions and milk production and composition of dairy cows in late lactation. The study was conducted using 24 multiparous Holstein Friesian cows in late lactation (253 $\pm 18 \mathrm{~d}$ in milk), and had a duration of $3 \mathrm{wk}$, including $2 \mathrm{wk}$ of adaptation to the diet and $1 \mathrm{wk}$ of measurements. Treatments consisted of two levels of concentrate supplementation (4 vs. $8 \mathrm{~kg} \mathrm{~d}^{-1} \mathrm{cow}^{-1}$; as-fed) offered daily in two equal rations during milking. In addition, diets included $2 \mathrm{~kg}$ DM grazed grass and $8 \mathrm{~kg}$ as-fed of grass hay. In week 3 of the study, $\mathrm{CH}_{4}$ emissions were measured for 7 consecutive days using the sulfur hexafluoride tracer technique. Average total DM intakes for the cows fed the 4 and $8 \mathrm{~kg}$ concentrate treatments were 12.3 and $15.6 \mathrm{~kg}$ DM, respectively. Treatments had no effect on milk yield, milk fat, or milk lactose concentrations. Milk protein concentration tended to increase in cows offered 8 $\mathrm{kg}$ of concentrate. Higher concentrate intake tended to increase cow body mass gain, but not condition score change. The $8 \mathrm{~kg}$ treatment increased total $\mathrm{CH}_{4}$ emissions $\left(\mathrm{g} \mathrm{d}^{-1}\right)$ by $10.7 \%$, whereas $\mathrm{CH}_{4}$ yield $\left(\mathrm{g} \mathrm{kg}^{-1} \mathrm{DM}\right.$ intake) was decreased by $12.7 \%$. Methane intensity ( $\mathrm{g} \mathrm{kg}^{-1}$ milk yield) was unaffected by treatments. Dietary concentrate supplementation for late lactation cows is ineffective in mitigating $\mathrm{CH}_{4}$ emission intensity, because animals do not respond with an increase in milk production.
\end{abstract}

Key words: Concentrate supplementation, hay, methane, pasture, ruminant, $\mathrm{SF}_{6}$.

\section{INTRODUCTION}

Methane $\left(\mathrm{CH}_{4}\right)$ is a greenhouse gas that absorbs radiation in the atmosphere contributing to climate change. Ruminants release methane into the atmosphere as a consequence of the digestion of feedstuffs in the rumen. Methane released represents a loss of ingested energy for ruminants that can range between 2\% and 12\% (Johnson and Johnson, 1995). In the last decades, research in strategies that can mitigate methane emissions from ruminants has intensified. In ruminants, the amount of $\mathrm{CH}_{4}$ emissions released is determined by the amount and composition of feedstuffs ingested (Hristov et al., 2013).

Supplementation of diets with concentrates are widely used to increase the production of ruminants (Purwin et al., 2016; Ruiz-Albarrán, et al., 2016), and is regarded as an effective methane mitigation strategy (Martin et al., 2010; Hristov et al., 2013), in particular, in intensive production systems with over 35\% grain inclusion in diets (Sauvant and 
Giger-Reverdin, 2009). Concentrates favor propionate production in the rumen offering an alternative hydrogen sink to methanogenesis, and lower ruminal $\mathrm{pH}$, which in turn inhibits methanogens directly and indirectly, as protozoal inhibition also decreases protozoal-associated methanogenesis (Grainger and Beauchemin, 2011). In addition, concentrates supply greater amounts of digestible nutrients than roughages, increasing animal productivity, and consequently, decreasing $\mathrm{CH}_{4}$ emission intensity (emissions generated for each kilogram of product), a phenomenon called the "dilution of maintenance effect" (Capper et al., 2009).

Previous research assessing the effects of moderate levels of dietary supplementation with concentrates $(1 \mathrm{vs} .5$ $\mathrm{kg}$ as-fed, corresponding to $5 \%$ and $23 \%$ of concentrate in the diet DM, respectively) found no effects on methane yield ( $\mathrm{g} \mathrm{kg}^{-1} \mathrm{DM}$ intake) or intensity ( $\mathrm{g} \mathrm{kg}^{-1}$ milk yield; Muñoz et al., 2015) of grazing dairy cows. However, increasing levels of concentrate supplementation $\left(2,4,6\right.$, and $8 \mathrm{~kg} \mathrm{~d}^{-1}$ animal $^{-1}$ as-fed) resulted in decreased methane yield (Jiao et al., 2014). Most of these studies were carried out on cows in early to mid-lactation. There is a knowledge gap concerning the effects of dietary supplementation with concentrates on enteric methane mitigation in late lactation cows. We hypothesized that levels of concentrate supplementation above $30 \%$ of the diet DM would decrease methane yield and intensity in late lactation dairy cows. The aim of this study was to investigate the effects of concentrate supplementation of the diet on enteric methane emissions and milk production and composition of late lactation dairy cows.

\section{MATERIALS AND METHODS}

The work was performed at Instituto de Investigaciones Agropecuarias, INIA Remehue (40³1' S, $73^{\circ} 03^{\prime}$ W; $65 \mathrm{~m}$ a.s.1.), Osorno, Chile, in full compliance with the requirements of the Chilean Law 20380 on Animal Protection and approval of the INIA Animal Ethics Committee.

\section{Animals, experimental design and dietary treatments}

Twenty four multiparous (mean parity $3.9 \pm 1.9$ ) late lactation Holstein Friesian cows with an average of $253 \pm 18 \mathrm{~d}$ in milk and an average milk production of $15.2 \pm 3.5 \mathrm{~kg}$ were used. At the onset of the experiment, average body mass of cows was $597 \pm 39 \mathrm{~kg}$ with a body condition score of $3.0 \pm 0.62$, scored on a 5-point scale (Edmonson et al., 1989). The study took place in autumn during April 2014 and had a duration of $3 \mathrm{wk}$, including $2 \mathrm{wk}$ of adaptation to the diet and 1 wk of measurements.

The cows were blocked into pairs according to days in milk and milk yield, and within each block, allocated at random to 1 of 2 treatments. Treatments consisted of two levels of concentrate supplementation per day: $4 \mathrm{vs} .8 \mathrm{~kg}$ (as-fed) cow ${ }^{-1}$. In addition, cows were offered a basal diet of $2 \mathrm{~kg}$ DM of grazed grass (measured above $3 \mathrm{~cm}$ ) animal ${ }^{-1} \mathrm{~d}^{-1}$, and $8 \mathrm{~kg}$ (asfed) of grass hay per animal per day. The concentrate was a commercial pelleted mixture (12.32 Concentrados Cisternas, Osorno, Chile) with an ingredient composition as follows ( $\mathrm{g} \mathrm{kg}^{-1}$, as-fed basis): steam-rolled corn (333), ground corn (210), rolled barley (143), wheat bran (133), dried distillers grains with solubles (48), ground beans (47) and rice bran (38), and a standard vitamin and mineral supplement (48). Both the grazed grass and grass hay used in the study were perennial ryegrass-based pasture. The two treatment groups were managed separately throughout the study.

\section{Feeding management and measurements}

Diet components were offered independently according to the following feeding management routine: During milking ( $c a .06: 00$ and 16:00 h) the concentrate was fed individually to cows in two equal rations and observations were made to confirm it was not refused. After the morning milking, cows were housed in two group feeding pens (one per treatment) with free stall accommodation and offered the daily ration of grass hay in a large feeding trough per pen (between 07:00 and 10:00 h). Then, cows in each treatment group walked to the grazing paddocks and grazed grass in adjacent paddocks under strip grazing using temporary electric fencing (between 10:00 and 16:00 h). After the evening milking, cows returned to the free stall accommodation for the night with what was left of the allocated grass hay. All cows had free access to fresh water for the duration of the study.

The grazing paddocks had a total area of 6 ha and were subdivided into six sub-paddocks of similar size, three subpaddocks per treatment that were grazed successively. Prior to the experiment, i.e. during the summer, paddocks had been grazed by a non-experimental dairy herd. The pasture was allowed to grow without being grazed for $c a .45 \mathrm{~d}$ prior to the 
study. During the study, treatment groups grazed adjacent grass paddocks that were of similar pre-grazing herbage mass. Cows on both treatments were offered the same target herbage allowance of $2 \mathrm{~kg} \mathrm{DM}$ animal-1 $\mathrm{d}^{-1}$. The target herbage allowance was obtained by adjusting the grazing area of each treatment according to their pregrazing herbage mass. The total area was grazed only once during the study and on average cows grazed each sub-paddock between 4 and $6 \mathrm{~d}$, depending on herbage mass. Access to the previous grazing area was restricted through the use of back-fencing. Animal intake measurements are described in the animal measurements section below.

Pregrazing herbage mass was measured once a week using four framed plots of $0.5 \mathrm{~m}^{2}(50 \times 100 \mathrm{~cm})$ selected at random in each sub-paddock. In each plot, the herbage was cut to $3 \mathrm{~cm}$ using a handheld electric clipper, collected in plastic bags, labelled, and weighed, with a 200 -g subsample being oven-dried $\left(60{ }^{\circ} \mathrm{C}\right.$ for $\left.48 \mathrm{~h}\right)$ for DM determination. Sward bulk density was calculated on each plot dividing herbage mass by cutting depth, determined through four measurements of herbage height per plot using a rising platemeter (diameter $36.5 \mathrm{~cm}$ and $3.0 \mathrm{~kg} \mathrm{~m}^{-2}$; Farmworks, Feilding, New Zealand) before and after cutting. The herbage area allocated daily to each treatment group was adjusted by daily estimates of the pregrazing herbage mass, calculated by multiplying the sward bulk density by the pregrazing sward height minus 3 . Pregrazing and postgrazing herbage heights were measured daily for each treatment using a rising platemeter (previously described), with 80 measurements per treatment made at random while crossing in zigzag path across each grazing area.

During the measurement week, four samples of grass hay, seven samples (one per day) of fresh grass per treatment (cut by hand at the postgrazing height of the previous day), and two samples of the concentrate were collected for analysis of chemical composition. All chemical analyses were conducted at Laboratorio de Nutrición Animal y Ambiente, INIA Remehue (Nch-ISO 17025), with the exception of gross energy, which was determined at Laboratorio de Nutrición Animal, Universidad Austral de Chile (Valdivia). Forage and concentrate samples were homogenized, dried at $60{ }^{\circ} \mathrm{C}$ for $48 \mathrm{~h}$, ground through a 1-mm sieve and analyzed for DM, crude protein (CP), neutral detergent fiber (NDF), acid detergent fiber (ADF), and ash concentrations according to the procedures outlined by the AOAC (1995). Dry matter digestibility was determined in vitro as by the method of Goering and Van Soest (1970) and metabolizable energy calculated as described by Garrido and Mann (1981). Gross energy was determined by oxygen bomb calorimetry (Bateman, 1970). All samples were analyzed in duplicate.

\section{Methane measurements}

Individual measurements of enteric methane emissions were conducted using the sulfur hexafluoride $\left(\mathrm{SF}_{6}\right)$ tracer gas technique (Johnson et al., 2007). Permeation tubes were filled in June 2013 by the National Institute of Water and Atmospheric Research, New Zealand, and followed the design described by Lassey et al. (2001). Initial charge of $\mathrm{SF}_{6}$ in the tubes was $2843 \pm 90 \mathrm{mg}$ and the calculated lifespan was of $454 \pm 138 \mathrm{~d}$. Tubes were calibrated by weighing them twice a week for $10 \mathrm{wk}$ while incubated at $39^{\circ} \mathrm{C}$ to produce a linear regression curve. The $\mathrm{SF}_{6}$ release rates were $2.6 \pm$ $0.53 \mathrm{mg} \mathrm{d}^{-1}$, and ranged from 2.5 to $4.8 \mathrm{mg} \mathrm{d}^{-1}$. On completion of calibration, tubes were inserted orally into the cows, 6 mo before the first methane measurement. During this period, the cows participated in another methane study carried out between October and November of 2013 (Muñoz et al., 2015).

For gas-collection, flushed PVC V-shaped canisters $(2.5 \mathrm{~L})$ were used. The flushing process involved two cycles of evacuating to $95 \mathrm{kPa}$, then filling with air, followed by a filling with ultra-high purity $\mathrm{N}$ gas. Flow restriction was achieved by means of a stainless-steel capillary tube (ALI5141321, Analítica Weisser, Santiago, Chile) cut to $30 \mathrm{~mm}$ length and then crimped using a bench vice until the desired flow was achieved. The pressure inside the canisters before and after sampling was measured using a digital gauge (Extech Manometer Model 407910; RS Components, Santiago, Chile) and recorded. After sample collection, ultra-high-purity $\mathrm{N}$ was added to each canister to achieve an over-pressure of $\sim 20 \mathrm{kPa}$ with the actual pressure achieved being measured with the same gauge and recorded. After a minimum of $1 \mathrm{~h}$ to allow for gas mixture, a sub-sample was taken from the canister using a 23 gauge needle attached to a $50 \mathrm{~mL}$ syringe. The first three $30 \mathrm{~mL}$ samples were vented to avoid sample contamination. Then, two $30 \mathrm{~mL}$ samples were taken and injected into two pre-evacuated glass vials with double-sided septa for later analysis.

Background concentrations of $\mathrm{SF}_{6}$ and $\mathrm{CH}_{4}$, both in the free stall accommodation and grazing paddocks, were sampled using mobile canisters. These canisters were transported by two additional cows per treatment group that did not have an $\mathrm{SF}_{6}$ permeation tube deployed in the rumen, and the inlet of their sample collection tubing was located behind their heads toward their back. Background concentrations were averaged per treatment to give a single estimate for all cows. 
Gas samples were analyzed in duplicate using a gas chromatograph (Perkin Elmer Clarus 600; Waltham, Massachusetts, USA). Samples were manually injected through a $1-\mathrm{mL}$ sample loop at a flow rate of $1 \mathrm{~mL} \mathrm{~min}^{-1}$ using $\mathrm{He}$ as the carrier gas. The $\mathrm{CH}_{4}$ column was an Elite-PLOT Q $(30 \mathrm{~m} \times 0.32 \mathrm{~mm} \mathrm{ID} \times 10 \mu \mathrm{m}$, Perkin Elmer $)$ and detection was by a flame ionization detector operated at $250{ }^{\circ} \mathrm{C}$. The $\mathrm{SF}_{6}$ column was a fused silica PLOT column RT Msieve $5 \mathrm{~A}(15 \mathrm{~m} \times 0.25 \mathrm{~mm}$ ID $\times 50 \mu \mathrm{m}$, Restek, Bellefonte, Pennsylvania, USA) and detection was by an electron capture detector operated at $300{ }^{\circ} \mathrm{C}$. The operating temperatures of the injector and the oven were 100 and $50{ }^{\circ} \mathrm{C}$, respectively.

\section{Animal measurements}

Throughout the study, individual milk yields were recorded automatically using DeLaval Alpro milk metering system (MM15; DeLaval International, Tumba, Sweden). On two consecutive days of the measurement week, milk samples proportional to milk weight were collected during am and pm milking, preserved with bactericide 2-bromo-2-nitropropane1,3-diol (bronopol, Surcell S.A., Buenos Aires, Argentina) and stored at $4{ }^{\circ} \mathrm{C}$. Composite samples were obtained by mixing the am and pm milking samples. Composite samples for each cow were analyzed for fat, protein, lactose, and milk urea nitrogen concentrations using infrared spectroscopy (MilkoScan 4000, Foss Electric, Hillerod, Denmark) at the Laboratorio Calidad de Leche (INIA Carillanca, Temuco; Nch-ISO 17025).

Cow body mass was recorded automatically after every milking, with mean body mass calculated weekly, and body condition score assessed at the beginning and end of the study by three operators using a 5-point score (Edmonson et al., 1989).

The daily group intake of grazed grass was calculated for each treatment group based on the disappearance of the herbage mass measured pre- and post-grazing (removed herbage) using a raising plate (previously described). Hay group intakes were calculated for each treatment based on the difference between daily offered and refused hay. There were no refusals of grass hay or concentrates during the study. As group intakes do not allow estimating variation among animals, equal intake among animals is assumed, acknowledging that this is evidently not true.

\section{Statistical analyses}

The individual animals were considered as the experimental units. The methane data were analyzed by repeated measures analysis using restricted maximum likelihood (REML) with a mixed model, including the random effect of the animal, fixed effects of the treatment and day of measurement, and interactions. Pasture chemical composition, grazing variables, feed intakes, and milk production and composition were analyzed as response variables to the effects of the treatment. All nonsignificant interactions $(\mathrm{P}>0.10)$ were eliminated from the models and the reduced model re-fitted. For the main effects of treatments and interactions, statistical significance was declared at $\mathrm{P}<0.05$ and tendencies at $0.05 \leq \mathrm{P} \leq 0.10$. The data were analyzed using JMP 12.1.0 (SAS Institute, Cary, North Carolina, USA) statistical software.

On the second day of measurements, one cow was removed from the group due to acute lameness; the absence in the rest of the measurement period was treated as missing data in the statistical analyses.

\section{RESULTS}

\section{Feed composition}

The chemical composition of the concentrate, grass hay and grazed grass are presented in Table 1 and the estimated chemical composition of the ration is presented in Table 2 . The $8 \mathrm{~kg}$ concentrate diet had a numerically higher $\mathrm{CP}$ and ME concentrations, and numerically lower neutral and acid detergent fiber concentrations, than the $4 \mathrm{~kg}$ concentrate diet.

\section{Pasture measurements}

Herbage allowance $(P=0.69)$, pre-grazing herbage height $(P=0.54)$, pre-grazing herbage mass $(P=0.67)$, grazed area $(P=0.90)$ and herbage removed by cows $(P=0.26)$ did not differ between the two treatments (Table 3$)$. However, feeding cows $8 \mathrm{~kg}$ of concentrate increased post-grazing herbage height $(\mathrm{P}=0.01)$ and post-grazing herbage mass $(\mathrm{P}=0.01)$ compared to feeding $4 \mathrm{~kg}$ of concentrate. 
Table 1. Nutrient composition of dietary components.

\begin{tabular}{lccc}
\hline Item & Concentrate $^{1}$ & Grass hay & Grazed grass \\
\hline $\mathrm{DM}, \mathrm{g} \mathrm{kg}^{-1}$ & 890 & 859 & 153 \\
Crude protein, $\mathrm{g} \mathrm{kg}^{-1} \mathrm{DM}$ & 193 & 62 & 231 \\
Gross energy, Mcal kg-1 DM & 4.02 & 4.26 & 4.25 \\
Metabolizable energy, Mcal kg-1 DM & 3.06 & 2.06 & 2.66 \\
Neutral detergent fiber, $\mathrm{g} \mathrm{kg}^{-1} \mathrm{DM}$ & 210 & 668 & 444 \\
Acid detergent fiber, $\mathrm{g} \mathrm{kg}^{-1} \mathrm{DM}$ & 71 & 395 & 246 \\
Ash, g kg-1 DM & 78 & 47 & 105 \\
in vitro DM digestibility, g kg-1 & 926 & 587 & 840 \\
\hline
\end{tabular}

${ }^{1}$ Commercial concentrate (Núcleo 12-32, Alimentos Cisternas S.A., Osorno, Chile) ingredient composition ( $\mathrm{g} \mathrm{kg}^{-1}$, as-fed basis): steamrolled corn 333, ground corn 210, rolled barley 143, wheat bran 133 , dried distillers grains with solubles 48 , ground beans 47 and rice bran 38 , and a standard vitamin and mineral supplement 48 .

Table 2. Diet component and chemical composition of the ration at two dietary concentrate levels.

\begin{tabular}{lcc}
\hline & \multicolumn{2}{c}{ Concentrate level } \\
\cline { 2 - 3 } Item & $4 \mathrm{~kg}$ & $8 \mathrm{~kg}$ \\
\hline Diet component, \% DM & 0.29 & 0.46 \\
$\quad$ Concentrate & \\
Grass hay & 0.56 & 0.44 \\
$\quad$ Grazed grass & 0.15 & 0.10 \\
Forage to concentrate ratio & $71: 29$ & $54: 46$ \\
Chemical composition & & \\
$\quad$ DM, g kg-1 & 765 & 801 \\
Crude protein, $\mathrm{g} \mathrm{kg}^{-1} \mathrm{DM}$ & 124 & 139 \\
Gross energy, Mcal kg ${ }^{-1} \mathrm{DM}$ & 4.18 & 4.14 \\
Metabolizable energy, $\mathrm{Mcal} \mathrm{kg}^{-1} \mathrm{DM}$ & 2.44 & 2.58 \\
Neutral detergent fiber, $\mathrm{g} \mathrm{kg}^{-1} \mathrm{DM}$ & 502 & 436 \\
$\quad$ Acid detergent fiber, $\mathrm{g} \mathrm{kg}^{-1} \mathrm{DM}$ & 279 & 232 \\
Ash, $\mathrm{g} \mathrm{kg}^{-1} \mathrm{DM}$ & 64 & 67 \\
in vitro DM digestibility, $\mathrm{g} \mathrm{kg}^{-1}$ & 722 & 767 \\
\hline
\end{tabular}

${ }^{1}$ Commercial concentrate (Núcleo 12-32, Alimentos Cisternas S.A., Osorno, Chile) ingredient composition ( $\mathrm{g} \mathrm{kg}^{-1}$, as-fed basis): steamrolled corn 333 , ground corn 210 , rolled barley 143 , wheat bran 133 , dried distillers grains with solubles 48 , ground beans 47 and rice bran 38 , and a standard vitamin and mineral supplement 48 .

Table 3. Effects of level of concentrate supplementation on herbage allowance, herbage height, herbage mass, grazed area and herbage removed by late lactation dairy cows.

\begin{tabular}{|c|c|c|c|c|}
\hline \multirow[b]{2}{*}{ Item } & \multicolumn{2}{|c|}{ Concentrate level } & \multirow[b]{2}{*}{ SE } & \multirow[b]{2}{*}{ P-Value } \\
\hline & $4 \mathrm{~kg}$ & $8 \mathrm{~kg}$ & & \\
\hline Herbage allowance, $\mathrm{kg}$ DM cow ${ }^{-1} \mathrm{~d}^{-1}$ & 1.8 & 1.9 & 0.12 & 0.69 \\
\hline Pregrazing herbage height, $\mathrm{cm}$ & 5.9 & 6.2 & 0.34 & 0.54 \\
\hline Postgrazing herbage height, $\mathrm{cm}$ & 3.0 & 3.3 & 0.08 & 0.01 \\
\hline Pregrazing herbage mass, $\mathrm{kg}$ DM ha ${ }^{-1}$ & 1195.0 & 1276.0 & 130.80 & 0.67 \\
\hline Postgrazing herbage mass, $\mathrm{kg} \mathrm{DM} \mathrm{ha}^{-1}$ & $-5.0^{*}$ & 138.0 & 34.40 & 0.01 \\
\hline Daily grazed area, $\mathrm{m}^{2} \mathrm{cow}^{-1}$ & 187.0 & 194.0 & 36.70 & 0.90 \\
\hline Herbage removed, $\mathrm{kg}$ DM cow ${ }^{-1} \mathrm{~d}^{-1}$ & 1.78 & 1.60 & 0.11 & 0.26 \\
\hline
\end{tabular}

*The cows ate slightly below $3 \mathrm{~cm}$, which was considered zero herbage mass. 
Milk production, milk composition and animal performance

Concentrate level had no effects on milk production $(\mathrm{P}=0.29)$, milk fat $(\mathrm{P}=0.71)$ or milk lactose $(\mathrm{P}=0.49)$ concentrations (Table 4). Milk protein concentration tended $(\mathrm{P}=0.07)$ to increase in the cows offered $8 \mathrm{~kg}$ of concentrate. Cows offered $8 \mathrm{~kg}$ of concentrate tended to increase $(\mathrm{P}=0.07)$ their body mass, with no change $(\mathrm{P}=0.50)$ in body condition.

\section{Feed intake and methane emissions}

Cows offered the $8 \mathrm{~kg}$ concentrate diet had a numerically higher feed intake and absolute methane production $(\mathrm{P}=0.03)$ than cows fed the $4 \mathrm{~kg}$ concentrate $\operatorname{diet}$ (Table 5). However, methane yield $(\mathrm{P}<0.01)$ and $\mathrm{Ym}$ (ratio of heat of combustion in methane released to gross energy intake expressed as percentage) decreased with the $8 \mathrm{~kg}$ concentrate level $(\mathrm{P}<0.01)$. Methane intensity $(\mathrm{P}=0.80)$ was not affected by treatments.

Table 4. Effects of concentrate supplementation level on milk yield, milk composition, body mass and condition score of late lactation dairy cows.

\begin{tabular}{|c|c|c|c|c|}
\hline & \multicolumn{2}{|c|}{ Concentrate level } & \multirow[b]{2}{*}{ SE } & \multirow[b]{2}{*}{ P-Value } \\
\hline & $4 \mathrm{~kg}$ & $8 \mathrm{~kg}$ & & \\
\hline Milk yield, $\mathrm{kg} \mathrm{d}^{-1}$ & 9.6 & 11.1 & 0.97 & 0.29 \\
\hline Milk protein, $\mathrm{g} \mathrm{kg}^{-1}$ & 37.1 & 42.0 & 0.18 & 0.07 \\
\hline Milk fat, $\mathrm{g} \mathrm{kg}^{-1}$ & 44.6 & 45.7 & 0.19 & 0.71 \\
\hline Milk lactose, $\mathrm{g} \mathrm{kg}^{-1}$ & 43.6 & 44.8 & 0.12 & 0.49 \\
\hline Milk solids, $\mathrm{g} \mathrm{kg}^{-1}$ & 138.5 & 146.1 & 0.30 & 0.09 \\
\hline Milk urea nitrogen, $\mathrm{mg} \mathrm{dL}^{-1}$ & 14.8 & 13.2 & 0.67 & 0.11 \\
\hline Fat-to-Protein ratio, $\mathrm{g} \mathrm{kg}^{-1}$ & 12.2 & 11.0 & 0.06 & 0.18 \\
\hline Somatic cell counts $\left(\times 10^{3}\right)$ & 360.0 & 208.0 & 138.80 & 0.44 \\
\hline Body condition score & 3.04 & 3.14 & 0.413 & 0.50 \\
\hline Body mass, $\mathrm{kg}$ & 594.0 & 632.0 & 13.70 & 0.07 \\
\hline
\end{tabular}

Table 5. Effects of concentrate supplementation level on feed DM intake ( $\mathrm{kg} \mathrm{DM} \mathrm{d}^{-1}$ ) and methane $\left(\mathrm{CH}_{4}\right)$ emissions of late lactation dairy cows.

\begin{tabular}{|c|c|c|c|c|}
\hline \multirow[b]{2}{*}{ Item } & \multicolumn{2}{|c|}{ Concentrate level } & \multirow[b]{2}{*}{ SE } & \multirow[b]{2}{*}{ P-Value } \\
\hline & $4 \mathrm{~kg}$ & $8 \mathrm{~kg}$ & & \\
\hline \multicolumn{5}{|l|}{ Total DM intake, $\mathrm{kg} \mathrm{d}^{-1}$} \\
\hline Grazed grass & 1.78 & 1.60 & - & - \\
\hline Grass hay & 6.98 & 6.89 & - & - \\
\hline Concentrate & 3.56 & 7.12 & - & - \\
\hline Total & 12.30 & 15.60 & - & - \\
\hline \multicolumn{5}{|l|}{ Methane emissions } \\
\hline $\mathrm{CH}_{4}, \mathrm{~g} \mathrm{~d}^{-1}$ & 290.0 & 321.0 & 9.08 & 0.03 \\
\hline $\mathrm{CH}_{4}, \mathrm{~g} \mathrm{~kg}^{-1} \mathrm{DM}$ intake & 23.6 & 20.6 & 0.63 & $<0.01$ \\
\hline $\mathrm{CH}_{4}, \mathrm{~g} \mathrm{~kg}^{-1}$ milk yield & 35.8 & 33.7 & 5.66 & 0.80 \\
\hline $\mathrm{Ym}^{1}, \%$ gross energy intake & 7.5 & 6.6 & 0.20 & $<0.01$ \\
\hline
\end{tabular}

${ }^{1}$ Methane energy as a percentage of gross energy intake.

\section{DISCUSSION}

Pasture is the main dietary component in dairy production systems of the south of Chile. The present study was carried out in autumn 2014, a season characterized by low precipitation compared to average (precipitations were 32\% and $21 \%$ lower than average for February and March, respectively; Agromet INIA database: http://agromet.inia.cl), which resulted in low pasture regrowth after the summer months. The lack of fresh pasture available for the study resulted in the inclusion of grass hay as a proxy for fresh forage. This situation is similar to the challenges faced by dairy farmers when pasture is not available and they must include conserved forages in the cows' diets.

Given the limited amount of pasture offered to cows in the present study $\left(<2 \mathrm{~kg} \mathrm{cow}^{-1}\right)$, it was not surprising to observe a lack of effects on pasture intake as a response to the amount of concentrate offered. Perhaps more surprising was the lack of effects of concentrate addition to the diet on grass hay intake, particularly for cows fed the high level of concentrate. 
Of the ration ingredients, grass hay had the highest NDF concentration and lowest DM digestibility, hence was the ration component most expected to place a constraint on DM intake (Allen, 2014). Given the lack of feed refusals observed in this study, it appears that cows in both treatment groups were not on an ad libitum feeding condition. The calculated CP concentration in the diet appears adequate for late lactation dairy cows (Moran, 2005).

\section{Methane emissions}

The present study, is one of the first methane measurement studies carried out in Chile. The mean methane yield obtained in this study (22.1 $\mathrm{g} \mathrm{kg}^{-1} \mathrm{DM}$ ) was similar to the methane yield reported for the control treatment of the study by Grainger et al. (2009) with early lactation dairy cows grazing ryegrass and offered $4.5 \mathrm{~kg} \mathrm{~d}^{-1} \mathrm{cow}^{-1}$ cracked triticale $\left(21.9 \mathrm{~g} \mathrm{~kg}^{-1}\right.$ DM). The mean methane yield in the present study was also close to the mean value reported by Charmley et al. (2016) for cattle fed predominantly forage diets $\left(20.7 \mathrm{~g} \mathrm{~kg}^{-1} \mathrm{DM}\right)$ in Australia. The mean Ym obtained in this study ( $7.0 \%$ gross energy intake) was slightly higher than the reference value used by the Intergovernmental Panel on Climate Change (2007) for greenhouse gas inventory purposes (6.5\% gross energy intake) and the mean value obtained by Charmley et al. (2016) for cattle on forage-based diets (6.3\% gross energy intake).

This study set out to determine the effects of dietary concentrate supplementation level on late lactation dairy cows' methane emissions and milk production. The results indicated that $8 \mathrm{~kg} \mathrm{~d}^{-1} \mathrm{cow}^{-1}$ dietary concentrate supplementation decreased methane yield ( $\mathrm{g} \mathrm{kg}^{-1} \mathrm{DM}$ intake) compared to $4 \mathrm{~kg}$ concentrate, but methane intensity ( $\mathrm{g} \mathrm{kg}^{-1}$ milk yield) was unaffected. It is well established that the proportion of concentrate in the diet affects methane production (Martin et al., 2010; Hristov et al., 2013). Diets based on concentrates with high starch concentration reduce ruminal pH and favor propionate over acetate production in the rumen, a competitive pathway for metabolic hydrogen relative to methanogenesis. This is especially true for diets with concentrate proportions of over $40 \%$ (Sauvant and Giger-Reverdin, 2009). Yet, when concentrate proportion is lower than $40 \%$, methane yield is less affected. Grass based dairy systems would seldom have levels of concentrate inclusion in the diet DM greater than $40 \%$.

Previous studies have examined the effects of concentrate supplementation to the diet of grazing dairy cow methane emissions. Lovett et al. (2005) compared the effects of $1 \mathrm{vs} .6 \mathrm{~kg} \mathrm{~d}^{-1} \mathrm{cow}^{-1}$ (as-fed) of concentrate based on fibrous by-products on methane emissions. The authors reported that the higher level of dietary concentrate supplementation increased DM intake, absolute methane production, milk yield, and milk fat and protein concentrations, compared to the lower concentrate level. Methane intensity (expressed per unit of fat corrected milk) tended to decrease with the higher concentrate level and methane yield was unaffected. In a similar study, Muñoz et al. (2015) reported that grazing dairy cows offered either 1 or $5 \mathrm{~kg}$ (as-fed) of concentrate had no differences in DM intake, but the higher concentrate level increased daily methane emissions and milk production. Yet, methane yield, and methane emissions intensity expressed as grams of methane emitted per kilogram of energy-corrected milk production, were unaffected by treatments. Another study with grazing dairy cows and a range of concentrate supplementation of between 2 and $8 \mathrm{~kg} \mathrm{~d}^{-1}$ animal ${ }^{-1}$ (as-fed), reported no effects of concentrate supplementation on daily methane emissions, but methane yield and intensity decreased with increasing concentrate level (Jiao et al., 2014). The differences observed in the results of these studies could be related to the amount and nature of the concentrates used. Overall, the methane decreasing effects of concentrate appear to be more marked with high levels of concentrate supplementation to the diet ( $>5 \mathrm{~kg})$.

\section{Milk production and animal performance}

In the present study, no differences were found in milk yield between the two treatments. This contrasts with the studies described previously, where higher concentrate proportions increased milk production (Lovett et al., 2005; Jiao et al., 2014; Muñoz et al., 2015). One of the factors that makes those studies different from the present one is the lactation stage of the cows used. We were working with cows with a mean of 253 days in milk at the beginning of the study compared to the 70, 131, and 231 days in milk of the cows from the Muñoz et al. (2015), Jiao et al. (2014) and Lovett et al. (2005) studies, respectively. Therefore, only Lovett et al. (2005) were working with late lactation cows. Yet, the milk production level of that study (mean of $20.1 \mathrm{~kg} \mathrm{~d}^{-1}$ ) with grazed grass and concentrates was much higher than the one obtained in this study (mean of $10.1 \mathrm{~kg} \mathrm{~d}^{-1}$ ).

In the present study, the higher concentrate level tended to increase body mass at the expense of milk production, compared to the lower concentrate level. This is consistent with net energy being partitioned towards body accretion 
rather than milk production in the late lactation cow. In late lactation milk production declines, yet energy requirements are still significant because of pregnancy and the need to increase body condition for the next lactation (Bauman and Currie, 1980; Roche et al., 2009). The short period of the study (3 wk) may account for the lack of effects on body condition score.

In the present study, the higher concentrate level tended to increase milk protein concentration. Increased energy intake resulted in increased ruminal microbial protein synthesis and glucose supply to the mammary gland sparing amino acids for milk protein synthesis (Palmquist, 1997).

\section{CONCLUSIONS}

A higher level of dietary concentrate supplementation $(8 \mathrm{~kg})$ of dairy cows from pastoral systems in late lactation increased daily methane emissions, decreased methane yield and had no effect on methane intensity, compared to a more moderate level of dietary concentrate supplementation $(4 \mathrm{~kg})$. These results disprove the hypothesis that increasing concentrate inclusion in the diets of late lactation cows grazing pasture supplemented with hay decreases methane absolute emissions or emissions intensity. Dietary supplementation with concentrate is not an effective strategy to mitigate methane emissions intensity of grazing dairy cows in late lactation.

\section{ACKNOWLEDGEMENTS}

This research was supported by Fondo Regional de Tecnología Agropecuaria, FONTAGRO/RF-1028-RG Project. The authors thank P. Fajardo of Universidad Mayor for her help with advising the thesis of the undergraduate student and INIA dairy staff for their assistance with field work.

\section{REFERENCES}

Allen, M.S. 2014. Drives and limits to feed intake in ruminants. Animal Production Science 54:1513-1524.

AOAC. 1995. Official methods of analysis. $16^{\text {th }}$ ed. Association of Official Analytical Chemists (AOAC), Arlington, Virginia, USA.

Bateman, J.V. 1970. Nutrición animal: manual de métodos analíticos. Herrero Hermanos Sucesores S.A., México.

Bauman, D.E., and Currie, W.B. 1980. Partitioning of nutrients during pregnancy and lactation: A review of mechanisms involving homeostasis and homeorhesis. Journal of Dairy Science 63:1514-1529. doi:https://doi.org/10.3168/jds.S0022-0302(80)83111-0.

Capper, J.L., Cady, R.A., and Bauman, D.E. 2009. The environmental impact of dairy production: 1944 compared with 2007. Journal of Animal Science 87:2160-2167. doi:10.2527/jas.2009-1781.

Charmley, E., Williams, S.R.O., Moate, P.J., Hegarty, R.S., Herd, R.M., Oddy, V.H., et al. 2016. A universal equation to predict methane production of forage-fed cattle in Australia. Animal Production Science 56:169-180.

Edmonson, A.J., Lean, I.J., Weaver, L.D., Farver, T., and Webster, G. 1989. A body condition scoring chart for Holstein dairy cows. Journal of Dairy Science 72:68-78.

Garrido, O., y Mann, E. 1981. Composición química, digestibilidad y valor energético de una pradera permanente de pastoreo a través del año. Universidad Austral de Chile, Facultad de Ciencias Agrarias, Valdivia.

Goering, H.K., and Van Soest, P.J. 1970. Forage fiber analyses (apparatus, reagents, procedures, and some applications). Agricultural Research Service (ARS), USDA, Washington, DC, USA.

Grainger, C., and Beauchemin, K.A. 2011. Can enteric methane emissions from ruminants be lowered without lowering their production? Animal Feed Science and Technology 166-167:308-320. doi:http://dx.doi.org/10.1016/j.anifeedsci.2011.04.021.

Grainger, C., Clarke, T., Auldist, M.J., Beauchemin, K.A., McGinn, S.M., Waghorn, G.C., et al. 2009. Potential use of Acacia mearnsii condensed tannins to reduce methane emissions and nitrogen excretion from grazing dairy cows. Canadian Journal of Animal Science 89:241-251.

Hristov, A.N., Oh, J., Firkins, J.L., Dijkstra, J., Kebreab, E., Waghorn, G., et al. 2013. Special topics- Mitigation of methane and nitrous oxide emissions from animal operations: I. A review of enteric methane mitigation options. Journal of Animal Science 91:5045-5069. doi:10.2527/jas.2013-6583.

Intergovernmental Panel on Climate Change. 2007. Summary for policymakers. In Solomon, S., Qin, D., Manning, M., Chen, Z., Marquis, M., Averyt, K.B., et al. (eds.) Climate Change 2007: The Physical Science Basis. Contribution of Working Group I to the Fourth Assessment Report of the IPCC. Cambridge University Press, Cambridge, UK. 
Jiao, H.P., Dale, A.J., Carson, A.F., Murray, S., Gordon, A.W., and Ferris, C.P. 2014. Effect of concentrate feed level on methane emissions from grazing dairy cows. Journal of Dairy Science 97:7043-7053.

Johnson, K.A., and Johnson, D.E. 1995. Methane emissions from cattle. Journal of Animal Science 73:2483-2492.

Johnson, K.A., Westberg, H.H., Michal, J.J., and Cossalman, M.W. 2007. The SF 6 tracer technique: methane measurement from ruminants. p. 33-67. In Makkar, H.P.S., and Vercoe, P.E. (eds.) Measuring methane production from ruminants. Springer, Dordrecht, The Netherlands.

Lassey, K.R., Walker, C.F., McMillan, A.M.S., and Ulyatt, M.J. 2001. On the performance of SF6 permeation tubes used in determining methane emission from grazing livestock. Chemosphere - Global Change Science 3:367-376.

Lovett, D.K., Stack, L.J., Lovell, S., Callan, J., Flynn, B., Hawkins, M., et al. 2005. Manipulating enteric methane emissions and animal performance of late-lactation dairy cows through concentrate supplementation at pasture. Journal of Dairy Science $88: 2836-2842$

Martin, C., Morgavi, D.P., and Doreau, M. 2010. Methane mitigation in ruminants: from microbe to the farm scale. Animal 4:351-365. doi:doi:10.1017/S1751731109990620.

Moran, J. 2005. Tropical dairy farming: feeding management for small holder dairy farmers in the humid tropics. Landlinks Press, CSIRO Publishing, Collingwood, Victoria, Australia.

Muñoz, C., Hube, S., Morales, J.M., Yan, T., and Ungerfeld, E.M. 2015. Effects of concentrate supplementation on enteric methane emissions and milk production of grazing dairy cows. Livestock Science 175:37-46. doi:http://dx.doi.org/10.1016/j.livsci.2015.02.001.

Palmquist, D.L. 1997. Can we feed for higher milk protein content? The Professional Animal Scientist 13:1-7. doi:10.15232/S1080-7446(15)32456-6.

Purwin, C., Wyzlic, I., Wielgosz-Groth, Z., Sobczuk-Szul, M., Michalski, J.P., and Nogalski, Z. 2016. Fattening performance of crossbred (Polish Holstein-Friesian x Hereford, Limousin or Charolais) bulls and steers offered high-wilted grass silage-based rations. Chilean Journal of Agricultural Research 76:337-342. doi:https://doi.org/10.4067/S0718-58392016000300011.

Roche, J.R., Friggens, N.C., Kay, J.K., Fisher, M.W., Stafford, K.J., and Berry, D.P. 2009. Invited review: Body condition score and its association with dairy cow productivity, health, and welfare. Journal of Dairy Science 92:5769-5801. doi:10.3168/jds.2009-2431.

Ruiz-Albarrán, M., Balocchi, O., Wittwer, F., and Pulido, R. 2016. Milk production, grazing behavior and nutritional status of dairy cows grazing two herbage allowances during winter. Chilean Journal of Agricultural Research 76:34-39. doi:https://doi.org/10.4067/S0718-58392016000100005.

Sauvant, D., et Giger-Reverdin, S. 2009. Modélisation des interactions digestives et de la production de méthane chez les ruminants. INRA Productions Animales 22:375-384. 